\title{
Quantitative Phytochemical Estimation and Evaluation of Antioxidant and Antibacterial Activity of Methanol and Ethanol Extracts of Heliconia rostrata
}

\author{
D. MOONMUN*, R. MAJUMDER, AND A. LOPAMUDRA \\ Department of Pharmaceutical Analysis, School of Pharmaceutical Sciences, Siksha 'O' Anusandhan University, \\ Bhubaneswar-751 003, India
}

Moonmun, et al.: Antioxidant and Antibacterial Activity of Heliconia rostrata

\begin{abstract}
Rhizomes of Heliconia rostrate, (family: Heliconiaceae) have been well known for antiophidic property. Ethnobotanically, rhizome of this plant has also been used to cure jaundice, intestinal pain and hypertension. This study aimed at evaluating the antioxidant and antimicrobial potency of two extracts of rhizomes of $H$. rostrata to find out the one, which exhibited better activity. Methanol and ethanol extract of the dried and defatted rhizomes were prepared and were subjected to qualitative and quantitative estimation of phytoconstituents, antioxidant assay and antibacterial evaluation. The methanol extract was found to give better yield than the ethanol extract. All phytoconstituents detected in the methanol extract were found in the ethanol extract also except for the glycoside content, which was found only in the methanol extract. Total phenolic and flavonoid content was higher in the ethanol extract compared to the methanol extract, whereas total tannin content was higher in the methanol extract. Both ethanol and methanol extracts exhibited antioxidant and antibacterial potency. The antioxidant activities of both extracts were found to be equal, while the ethanol extract exerted significantly higher antibacterial activity compared to the methanol extract.
\end{abstract}

Key words: Heliconiaceae, rhizome, phytoconstituents, antioxidant, antimicrobial

Medicinal plants offer alternative therapies with spectacular opportunities ${ }^{[1]}$. Heliconia rostrata, popularly known as false bird of paradise and hanging lobster claw (family: Heliconiaceae) is a shrub that is reported to contain calcium, nitrogen, potassium, magnesium, iron, phosphorous, chlorine, sulphur, sugar, carbohydrate, starch and protein ${ }^{[2]}$. This plant is reported to be well known for antiophidic property ${ }^{[3]}$. Ethnobotanically, the traditional people of Malaysia used these rhizomes to cure jaundice, intestinal pain and hypertension $^{[4]}$. However, not much of experimental evidence was documented.

Oxygen, the most important component for the survival of living being is highly reactive and can do serious damage to healthy cells of the body as a free radical. Oxidation produces free radicals, which can start chain reactions in the cell leading to cell damage and even cell death ${ }^{[5]}$. An antioxidant terminates these radical reactions by removing free radical intermediates, which causes ageing and disease like atherosclerosis, cancer, cardiovascular diseases and CNS disorders ${ }^{[6]}$ thus, play a vital role in inhibiting or delaying the oxidation at the cellular level ${ }^{[7]}$. Synthetic antioxidants, butylatedhydoxytoluene

${ }^{*}$ Address for correspondence E-mail: moonmundhara@gmail.com

January-February 2017
(BHT), butylatedhydroxyanisole (BHA) and tert-butyl hydroquinone (TBHQ) are being evaluated in many countries for their potential health hazard and have been found to promote liver damage and causing cancer to laboratory animals ${ }^{[8]}$. In comparison, the plant sources prove to have less or no side effect ${ }^{[6]}$, thus channelizing the interest towards the nature for antioxidant potency.

Researchers now are focusing on the natural products to develop new molecules for the treatment of microbial diseases, since current trend shows the failure of the existing antimicrobials in treating the infectious diseases ${ }^{[9,10]}$. Thus, there exists requirement of some novel antimicrobials for the obliteration of new opportunistic pathogens ${ }^{[11]}$. To identify the possible medicinal potency of any plant, the in vitro antibacterial studies and the antioxidant activity assay have to be carried out as the first step ${ }^{[12]}$. Present study

This is an open access article distributed under the terms of the Creative Commons Attribution-NonCommercial-ShareAlike 3.0 License, which allows others to remix, tweak, and build upon the work non-commercially, as long as the author is credited and the new creations are licensed under the identical terms

Accepted 14 January 2017

Revised 09 November 2016

Received 04 July 2016

Indian J Pharm Sci 2017;79(1): 79-90 
aimed at evaluating the antioxidant and antimicrobial potency of two extracts of rhizomes of $H$. rostrata to find out the extract, which produced the better activity to carry out further studies.

\section{MATERIALS AND METHODS}

Plant of H. rostrata was collected from and authenticated at the Regional Plant Resource Centre (RPRC), Bhubaneswar (Authentication Field Number, MDHR1). These plants were cultivated in the house garden for 6 mon before using them for the experimental purpose and were harvested in the early morning of first week of September. All the chemicals and solvents used in the study were of analytical grade procured from the Merck Specialities Private Limited.

Fresh rhizomes of $H$. rostrata were collected, washed in tap water to get rid of any contaminants ${ }^{[13]}$ and then dried to remove water from the surface of the rhizomes. The rhizomes were cut into small pieces and dried under shade at room temperature for $7 \mathrm{~d}$. The dried rhizomes were ground to a coarse powder ${ }^{[14]}$ and defatted using petroleum ether. Equal quantities of defatted dried rhizome of $H$. rostrata were subjected to maceration with methanol and ethanol for $72 \mathrm{~h}$ each. It was then filtered and concentrated (rotaryevaporator) to obtain dried extracts rhizome methanol extract (RME) and rhizome ethanol extract (REE). The $\%$ yield was calculated using the following Eqn.: yield $(\%)=$ (weight of extract in $\mathrm{g} /$ weight of defatted dried rhizomes in $\mathrm{g}) \times 100$.

\section{Phytochemical screening:}

The extracts were screened for the presence of alkaloids, glycosides, steroids and triterpenoids, flavonoids, proteins and amino acids, carbohydrates and reducing sugars, tannins and saponins using standard methods ${ }^{[15-17]}$.

\section{Test for glycosides:}

Half a gram of powdered extract was diluted to $5 \mathrm{ml}$ with water followed by the addition of $2 \mathrm{ml}$ of glacial acetic acid and a drop of ferric chloride solution. To this, $1 \mathrm{ml}$ of concentrated sulphuric acid was added very slowly. Presence of glycosides would result appearance of a brown ring at the interface ${ }^{[15]}$.

\section{Test for alkaloids:}

To $0.5 \mathrm{~g}$ of powdered RME and REE, $1.5 \mathrm{ml}$ of ammonia solution was added. This was allowed to stand for some time and then $5 \mathrm{ml}$ of chloroform was added, shaken well and then filtered through a Whatman filter paper. The filtrate was warmed on a water bath to evaporate chloroform. One millilitre of Mayer's reagent was added to it. Formation of a cream colour precipitate indicated the presence of alkaloids ${ }^{[16]}$. To $0.5 \mathrm{~g}$ of extract $5 \mathrm{ml}$ of $1 \%$ of aqueous $\mathrm{HCl}$ was added, warmed on a water bath for a few minutes and filtered. To the filtrate few drops of Dragendorff's regent was added. Turbidity or precipitation indicates the presence of alkaloids ${ }^{[17]}$.

\section{Test for steroids and triterpenoids:}

Liebermann Burchard reaction was performed by adding to $5 \mathrm{ml}$ of the extract solution, $2 \mathrm{ml}$ of acetic anhydride followed by $2 \mathrm{ml}$ of concentrated sulphuric acid. Change of violet colour to blue indicated the presence of steroids ${ }^{[17]}$. To $5 \mathrm{mg}$ of extract, $2 \mathrm{ml}$ of chloroform was added followed by the addition of $1 \mathrm{ml}$ of acetic anhydride and $1 \mathrm{ml}$ of concentrated sulphuric acid. Formation of reddish violet colour indicates the presence of triterpenoids ${ }^{[16]}$.

\section{Test for flavonoids:}

Five millilitres of dilute ammonia was added to $0.5 \mathrm{~g}$ of extract dissolved in water. One millilitre of concentrated sulphuric acid was added to it. Disappearance of yellow colour on standing indicated the presence of flavonoids ${ }^{[15]}$. Formation of yellow colour on addition of few drops of $1 \%$ aluminium chloride indicates the presence of flavonoids ${ }^{[15]}$.

\section{Test for proteins and amino acids:}

Biuret test was performed by adding to $3 \mathrm{ml}$ of extract, $4 \%$ sodium hydroxide and a few drops of $1 \%$ copper sulphate solution. Presence of proteins or amino acids is indicated by the formation of a violet or pink colour ${ }^{[17]}$.

\section{Test for carbohydrates and reducing sugars:}

Molisch test was performed by the addition to $5 \mathrm{ml}$ of aqueous extract, 2 drops of alcoholic alpha napthol solution and shaking the mixture well. To this mixture concentrated sulphuric acid was added through the walls of the test tube. Appearance of a violet ring indicates the presence of carbohydrates ${ }^{[17]}$. Fehling test was done by adding to $1 \mathrm{ml}$ of Fehling A solution, 1 $\mathrm{ml}$ of Fehling $\mathrm{B}$ solution and boiling the mixture for a minute. Then equal amount of extract solution was added and heated in a water bath for 5 to $10 \mathrm{~min}$. Appearance of a brick red precipitate indicated the presence of reducing sugars in the extract ${ }^{[17]}$. 


\section{Test for tannins:}

Five millilitres of $\mathrm{n}$-butanol $\mathrm{HCl}$ solution was added to $2 \mathrm{ml}$ of extract solution in a test tube. This mixture was warmed on a water bath at $95^{\circ}$ for an hour. Presence of tannin is indicated by the appearance of a red colour ${ }^{[15]}$. Five millilitres of chloroform followed by $1 \mathrm{ml}$ of acetic anhydride was added to $0.5 \mathrm{ml}$ of extract solution in a test tube. Then $1 \mathrm{ml}$ of concentrated sulphuric acid was added through the walls of the test tube. Appearance of a green colour indicated the presence of tannin ${ }^{[16]}$.

\section{Test for saponins:}

Five millilitres of distilled water was added to $0.5 \mathrm{~g}$ of dry extract and shaken vigorously. Stable foam indicated the presence of saponins. Further, formation of an emulsion on addition of 3 drops of olive oil and vigorous shaking also indicated the saponin presence in the extract ${ }^{[15]}$.

\section{Quantitative estimation of total phenolic content (TPC):}

TPC was estimated using Folin-Ciocalteu reagent (FCR) with gallic acid as the standard ${ }^{[18]}$. FCR being sensitive to reducing compounds including polyphenols produce blue colour upon reaction. Absorbance of each was checked at $760 \mathrm{~nm}$ spectrophotometrically. Standard curve was prepared with different dilutions of gallic acid in ethanol and methanol. All the determinations were done in triplicate. The TPC is expressed in $\mathrm{mg}$ gallic acid equivalent (GAE)/g dry extract.

\section{Quantitative estimation of total tannin content (TTC):}

TTC was estimated using Folin-Denis reagent (FDR) and taking tannic acid as the standard ${ }^{[19]}$. The solution was mixed properly and the absorbance of each was checked at $700 \mathrm{~nm}$ spectrophotometrically. Standard curve was prepared with standard dilutions of tannin acid in ethanol and methanol. All the determinations were done in triplicate. The TTC is expressed in $\mathrm{mg}$ tannic acid equivalent (TAE) per gram dry extract.

\section{Quantitative estimation of total flavonoid content (TFC):}

TFC was determined taking quercetin as the standard by aluminium chloride method ${ }^{[20]}$. Absorbance was determined spectrophotometrically at $510 \mathrm{~nm}$. Standard curve was prepared with quercetin solution prepared in ethanol and methanol. All the determinations were done in triplicate. The TFC is expressed in mg quercetin equivalent/g dry extract.
DPPH (2,2-diphenyl-1-picrylhydrazyl) radical scavenging assay ${ }^{[21]}$ :

DPPH radical scavenging assay is one of the common methods of determining the antioxidant activity of plant extracts. A working solution of DPPH was prepared by diluting stock solution of DPPH $(0.24 \mathrm{mg} / \mathrm{ml})$ using methanol to achieve an absorbance of $0.980 \pm 0.020$ at $517 \mathrm{~nm}$. Three millilitres of working solution of DPPH was mixed with $100 \mu$ l of dilution of extracts and kept undisturbed at room temperature for $15 \mathrm{~min}$. Absorbance was taken at $517 \mathrm{~nm}$. Ascorbic acid was used as the standard. Percent scavenging of DPPH (\% inhibition) was calculated for different concentration $(50-250 \mu \mathrm{g} / \mathrm{ml})$ of extract and standard using the following Eqn., DPPH \%scavenging = $(\mathrm{A} 0-\mathrm{A} 1 /$ $\mathrm{A} 0) \times 100$, where, A0 is the absorbance of the control at $15 \mathrm{~min}$ and $\mathrm{A} 1$ is the absorbance of the sample at 15 min. The concentration of extract at which $50 \%$ inhibition is observed $\left(\mathrm{IC}_{50}\right)$ is calculated in $\mu \mathrm{g} / \mathrm{ml}$.

ABTS (2,2'-azino-bis(3-ethylbenzothiazoline-6sulfonic acid)diammonium salt) radical scavenging $\operatorname{assay}^{[22]}$ :

ABTS radical scavenging assay is another method of determining the antioxidant capacity of plant extracts. A total of $14 \mathrm{mmol} / 1$ ABTS solution and $4.9 \mathrm{mmol} / \mathrm{l}$ potassium persulphate solution was mixed and kept in dark at room temperature for $16 \mathrm{~h}$ to produce $\mathrm{ABTS}^{+}$ cation radicals. This solution was diluted with ethanol to attain an absorbance of $0.700 \pm 0.020$ at $745 \mathrm{~nm}$. Three millilitres of ABTS working solution was mixed with $100 \mu \mathrm{l}$ of dilution of extracts, mixed well and kept at room temperature for $5 \mathrm{~min}$. Absorbance was measured spectrophotometrically at $745 \mathrm{~nm}$. Ascorbic acid was used as the standard. Percent scavenging of ABTS radical (\%inhibition) was calculated for different concentrations $(50-250 \mu \mathrm{g} / \mathrm{ml})$ of extract and standard using the following Eqn., ABTS \% scavenging = $(\mathrm{A} 0-\mathrm{A} 1 / \mathrm{A} 0) \times 100$, where, $\mathrm{A} 0$ is the absorbance of the control at $5 \mathrm{~min}$ and $\mathrm{A} 1$ is the absorbance of the sample at $5 \mathrm{~min}$. The concentration of extract at which $50 \%$ inhibition is observed $\left(\mathrm{IC}_{50}\right)$ is calculated in $\mu \mathrm{g} / \mathrm{ml}$.

\section{Hydrogen peroxide $\left(\mathrm{H}_{2} \mathrm{O}_{2}\right)$ assay ${ }^{[23]}$ :}

$\mathrm{H}_{2} \mathrm{O}_{2}$ assay was performed with ascorbic acid as the standard. A solution of $\mathrm{H}_{2} \mathrm{O}_{2}(40 \mathrm{mM})$ was prepared in phosphate buffer $(0.2 \mathrm{~mol} / \mathrm{l}, \mathrm{pH} 7.4)$. One hundred microlitres of different concentrations $(50-250 \mu \mathrm{g} / \mathrm{ml})$ of the extracts were added to $3 \mathrm{ml}$ of $\mathrm{H}_{2} \mathrm{O}_{2}$ solution and kept for $10 \mathrm{~min}$. The absorbance was measured 
spectrophotometrically at $230 \mathrm{~nm}$ after $10 \mathrm{~min}$ of reaction time. $\mathrm{H}_{2} \mathrm{O}_{2} \%$ scavenging (\%inhibition) was calculated for different concentration of extract and standard using the following Eqn., $\mathrm{H}_{2} \mathrm{O}_{2} \%$ scavenging $=(\mathrm{A} 0-\mathrm{A} 1 / \mathrm{A} 0) \times 100$, where, $\mathrm{A} 0$ is the absorbance of the control after $10 \mathrm{~min}$ and $\mathrm{A} 1$ is the absorbance of the sample at $10 \mathrm{~min}$. The concentration of extract at which $50 \%$ inhibition is observed $\left(\mathrm{IC}_{50}\right)$ is calculated in $\mu \mathrm{g} / \mathrm{ml}$.

\section{Phosphomolybdate assay ${ }^{[18]}$ :}

Total antioxidant activity (TAC) of REE and RME was determined using ascorbic acid as the standard. Phosphomolybdate reagent was prepared by mixing $100 \mathrm{ml}$ of $28 \mathrm{mM}$ sodium phosphate, $100 \mathrm{ml}$ of 0.6 $\mathrm{M}$ sulphuric acid and $100 \mathrm{ml}$ of $4 \mathrm{mM}$ ammonium molybdate solutions. To $3 \mathrm{ml}$ of phosphomolybdate reagent, $300 \mu \mathrm{l}$ of different concentrations $(50-250 \mu \mathrm{g} /$ $\mathrm{ml}$ ) of extract solution were added and incubated in the dark for $90 \mathrm{~min}$ at $95^{\circ}$. The absorbance was measured spectrophotometrically at $765 \mathrm{~nm}$. TAC \%scavenging $=(\mathrm{A} 0-\mathrm{A} 1 / \mathrm{A} 0) \times 100$, where, $\mathrm{A} 0$ is the absorbance of the control after $10 \mathrm{~min}$ and $\mathrm{A} 1$ is the absorbance of the sample at $10 \mathrm{~min}$. The concentration of extract at which $50 \%$ inhibition is observed $\left(\mathrm{IC}_{50}\right)$ is calculated in $\mu \mathrm{g} / \mathrm{ml}$.

\section{Reducing power assay ${ }^{[24]}$ :}

Equal volume of $0.2 \mathrm{M}, \mathrm{pH} 6.6$ phosphate buffer and $1 \%$ ferrocyanate were mixed with different concentration $(50-250 \mu \mathrm{g} / \mathrm{ml})$ of extracts and standard (ascorbic acid) and incubated for $20 \mathrm{~min}$ at $50^{\circ}$. To $5 \mathrm{ml}$ of the mixture $2.5 \mathrm{ml}$ of $10 \%$ trichloroacetic acid was added and centrifuged at $3000 \mathrm{rpm}$ for 10 min. To the supernatant $2.5 \mathrm{ml}$ of distilled water and $0.5 \mathrm{ml}$ of $1 \%$ ferric chloride was added. Absorbance was measured at $700 \mathrm{~nm}$. Higher reducing power is indicated by high absorbance. Reducing power is a reflection of antioxidant activity of any compound. These compounds have the ability to donate electrons, thus reducing the oxidized intermediates and acting as antioxidants $^{[25]}$.

\section{Antibacterial study:}

The antibacterial activity of the plant extracts was tested against three Gram-positive bacteria, Bacillus stereothermophillus (American Type Culture Collection (ATCC) 7953), B. subtilis (Microbial Type Culture Collection (MTCC) 441) and Staphylococcus aureus (ATCC 29737) and six Gramnegative bacteria, Escherichia coli (ATCC 11229),
Klebsiella pneumoniae (MTCC 9401), Salmonella enterica (MTCC 9844), Pseudomonas aeruginosa (ATCC 9027), Vibrio cholera (ATCC 51395) and Acinetobacter baumannii (ATCC 17978). All the microorganisms with ATCC Number were obtained from the Laboratory of Microbiology, NICU, SUM Hospital, Bhubaneswar. All the microorganisms with MTCC Number were obtained from MTCC and Gene Bank, Institute of Microbial Technology, Chandigarh.

\section{Well diffusion method for determination of zone of inhibition:}

The antibacterial activity evaluation of RME and REE was performed using the well diffusion method ${ }^{[26,27]}$. The inoculum of the microorganism was prepared from bacterial cultures. Fifteen millilitres of nutrient agar (HiMedia) medium was poured in clean sterilized Petri-plates and allowed to cool and solidify. Hundred microlitres of broth of bacterial stain was pipetted out and spread over the medium evenly with a spreading rod till it dried properly. Wells of $6 \mathrm{~mm}$ in diameter were bored using a sterile cork borer. Solutions of both the extracts $(10 \mathrm{mg} / \mathrm{ml})$ in dimethyl sulphoxide (DMSO) were prepared. Hundred microlitres of plant extract solutions was added to the wells. The Petriplates were incubated at $37^{\circ}$ for $24 \mathrm{~h}$. Streptomycin (1 $\mathrm{mg} / \mathrm{ml}$ ) was used as a positive control and DMSO was taken as negative control. Antibacterial activity was evaluated by measuring the diameters of the zones of inhibition (ZI). All the determinations were performed in triplicate.

\section{Minimum inhibitory concentration (MIC) and minimum bactericidal concentration $(\mathrm{MBC})^{[28]}$ :}

Stock solutions of the strength $100 \mathrm{mg} / \mathrm{ml}$ of REE and RME were prepared in DMSO. Sterilized nutrient broth was cooled and supplemented with $0.05 \%$ 2,3,5-triphenyltetrazolium chloride. Nutrient broth, extract solution and $100 \mu \mathrm{l}$ of bacterial inoculum were added to each well to achieve concentrations ranging $10 \mathrm{mg} / \mathrm{ml}$ to $1 \mathrm{mg} / \mathrm{ml}$ of each extract. The plates were incubated at $37^{\circ}$, in aerobic conditions for $24 \mathrm{~h}$. The $11^{\text {th }}$ well was kept as the negative control without any added extract. Growth of the bacteria was indicated by the formation of pink colour in the wells. MIC was the lowest concentration of REE/RME that inhibited the formation of pink colour, thereby inhibiting the growth of the bacteria in the well. For the determination of MBC, bacteria from each inhibited well was subcultured on nutrient agar plate and incubated for further $24 \mathrm{~h}$ at $37^{\circ}$ under aerobic conditions. The minimum 
dilution at which no bacterial growth was observed was considered as the MBC of the extracts.

\section{Statistical analysis:}

Statistical analysis was performed using SPSS version 20. One-way analysis of variance (ANOVA) was used to detect the significant difference between the extracts in antioxidant studies and antimicrobial study. A probability value $\mathrm{P} \leq 0.05$ is considered to represent a statistically significance difference.

\section{RESULT AND DISCUSSION}

Extraction of defatted rhizomes of $H$. rostrata was carried out using methanol and ethanol as liquid extractor to yield dried RME (blackish brown powder) and REE (reddish brown powder). Defatting of plant parts is a pre-extraction process, which is expected to remove undesirable fatty substances from the plant powder. This process also enhanced the polarity of phenolic compounds thus increasing their yield in the extract ${ }^{[29]}$. Percent yield of RME (5.38\%) was found to be more than that of REE $(2.25 \%)$ as shown in fig. 1. Phytochemical screening results of REE and RME have been presented in Table 1, which demonstrated the absence of alkaloids and steroids in both these extracts. Both REE and RME contained flavonoids, proteins and amino acids, carbohydrates and reducing sugars, tannins and saponins. Glycosides were found to be present in RME only. Absence of steroids and triterpenoids might be due to the defatting prior to the extraction of rhizomes with ethanol and methanol.

Literature review on this plant collected from different regions of the world show some contradicting results. The $70 \%$ ethanol extract of rhizomes of $H$. rostrata collected from Areado city, Brazil, displayed the presence of flavonoids and absence of alkaloids, tannin and saponin ${ }^{[30]}$. Meanwhile, rhizomes of $H$. rostrata collected from Columbia showed the presence of terpenoids, proteins, phenolic compounds and carbohydrates $^{[3,31]}$, when percolated with ethanol without defatting. This demonstrated that with the change in the solvent and method of extraction, different phytochemical constituents get extracted. Influence of geographical region from which the plant is collected also a likely factor contributing to differences in phytoconstituents.

The results of quantitative estimation of TPC, TTC and TFC along with the standard curves plotted have been depicted in fig. 2A, 2B, 2C, 2D, 2E and $2 \mathrm{~F}$. It is clearly evident from the results that TPC and TFC

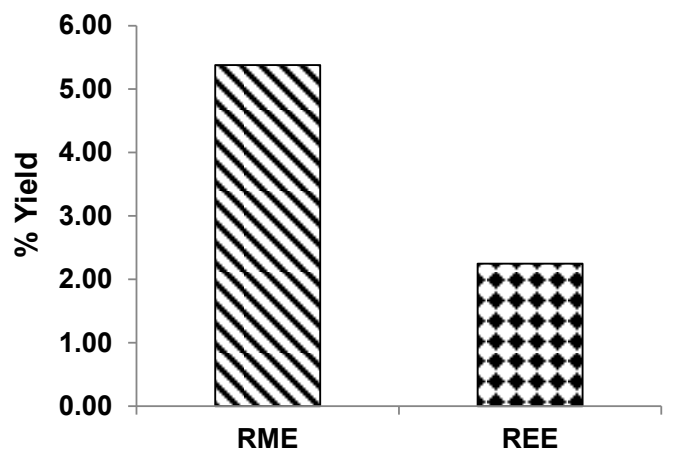

Fig. 1: \% Yield of extracts

RME: rhizome methanol extract, REE: rhizome ethanol extract

TABLE 1: PHYTOCONSTITUENTS IN RME AND REE

\begin{tabular}{lcc}
\hline Phytoconstituents & RME & REE \\
\hline Alkaloid & - & - \\
Glycoside & + & - \\
Steroids and triterpenoids & - & - \\
Flavonoids & + & + \\
Proteins and amino acids & + & + \\
Carbohydrates and reducing sugar & + & + \\
Tannin & + & + \\
Saponin & + & + \\
\hline+ ' denotes presence and '-' denotes absence of phytoconstituents
\end{tabular}

in REE were greater than the TPC and TFC of RME. RME contained TTC more than that in REE.

Antioxidant activity of any extract could possibly be attributedtonumerousmechanisms. Binding oftransition metal ion catalyst, radical scavenging, decomposition of peroxide, reducing capacity, prevention of continued hydrogen abstraction and prevention of chain initiation are some of these mechanisms. DPPH is a stable free radical with an absorption band at 515 $\mathrm{nm}$. When reduced by an antioxidant to form DPPH, the natural deep violet colour of DPPH changes to pale yellow ${ }^{[32]}$. The change in the colour would be proportional to the strength of the antioxidants and a significant decrease in the absorbance of the reaction mixture indicates significant free radical scavenging activity of the test material. ABTS radical scavenging assay, unlike DPPH radical scavenging assay can be used at a different $\mathrm{pH}$ level, thus making this method useful in studying the antioxidant activity at varying $\mathrm{pH}$ levels. Moreover ABTS model can evaluate the scavenging activity of both polar and non-polar samples ${ }^{[22]}$. The reaction time of ABTS is lower than that of DPPH. Bluish green coloured ABTS radical was produced by reacting ABTS with the oxidising agent, potassium persulfate overnight. Reduction of ABTS radical by hydrogen donating antioxidant is measured spectrophotometrically ${ }^{[33]}$. Results from the DPPH and ABTS radical scavenging assays were shown in fig. 3A 

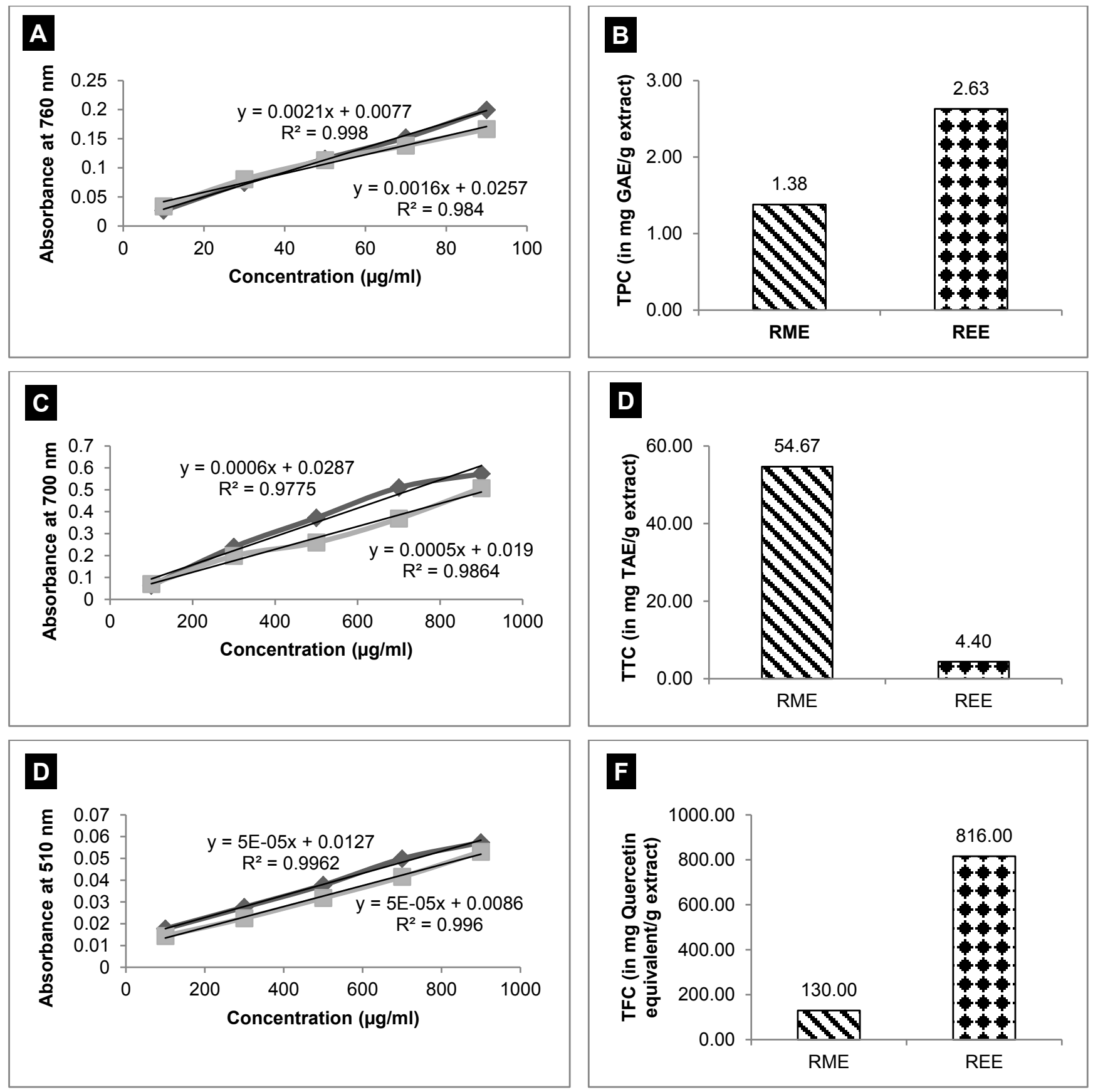

Fig. 2: Quantitative estimation of phytoconstituents

Standard curve of gallic acid (A), tannic acid (C) and quercetin (E) in both methanol and ethanol. Comparison by graphical representation of the total phenolic content (B), total tannin content (D) and total flavonoid content (F) in RME: rhizome methanol extract, REE: rhizome ethanol extract. $A-\square-$ gallic acid in methanol, $-\downarrow$ gallic acid in ethanol; $\mathrm{C}-\square-\square$ tannic acid in methanol, $\longrightarrow$ tannic acid in ethanol; $E-\downarrow-$ quercetin in methanol, $-\downarrow$ quercetin in ethanol

and $3 \mathrm{~B} . \mathrm{H}_{2} \mathrm{O}_{2}$ scavenging activity of the plant extracts was measured spectrophotometrically, which indicated the disappearance of $\mathrm{H}_{2} \mathrm{O}_{2}$ at $230 \mathrm{~nm}^{[34]}$. $\mathrm{H}_{2} \mathrm{O}_{2}$ forms a hydroxyl radical in the cells, which can be toxic to them. Thus, removal of $\mathrm{H}_{2} \mathrm{O}_{2}$ is very important ${ }^{[35]}$. Results of $\mathrm{H}_{2} \mathrm{O}_{2}$ scavenging activity have been shown in fig. 3C. Phosphomolybdate assay measures the capacity of an extract to destroy a free radical by transferring an electron to the later. Antioxidants present in the extract reduce molybdate (VI) to molybdate (V) and this can be measured spectrophotometrically at $700 \mathrm{~nm}^{[36]}$. Result of phosphomolybdate assay was illustrated in fig. 3 D.

The $\mathrm{IC}_{50}$ values of REE and RME were depicted in Table 2. The $\mathrm{IC}_{50}$ value of REE is lower than RME, which could be attributed to the fact that REE possessed better antioxidant property than RME. The antioxidant activity demonstrated a positive correlation with TPC ${ }^{[1]}$. Moreover, flavonoids also act as scavengers to various 
oxidising species $^{[37]}$. Therefore, it was quite sensible to determine the TPC and TFC in the plant extract. TPC and TFC of REE have been found to be more than that of RME as evident from fig. 3B and 3D, respectively, and this could possibly explain why the $\mathrm{IC}_{50}$ of REE is lower than that of RME.

Depending on the reducing power of the testing compound, the yellow colour of the Fe(III) changes to Fe(II), Perl's Prussian blue which can be measured spectrophotometrically at $700 \mathrm{~nm}^{[21]}$. The reductive capacity of REE and RME was compared to that of ascorbic acid in fig. 4. It is observed that there existed a positive correlation between the antioxidant activity and reducing power of REE and RME. Like the antioxidant activity study, reducing power of REE and
RME also increased with increasing concentrations of the extract. Reductions, which contribute to the antioxidant activity by breaking the free radical chain and donating a hydrogen atom, are also responsible for the reducing properties ${ }^{[38]}$. Since all the tests performed for in vitro antioxidant activity demonstrated significant activity as shown in the Table 3 , there is no significant difference between the results obtained from the antioxidant activity determination and reducing power study of REE and RME.

In the present study, the antibacterial potential of REE and RME have been tested against three Grampositive and six Gram-negative bacteria. The well diffusion method of testing antibacterial activity has been widely considered to be better and is

\section{TABLE 2: IC ${ }_{50}$ VALUES OF RME AND REE}

\begin{tabular}{lcccc}
\hline Testing samples & \multicolumn{3}{c}{$\mathrm{IC}_{50}(\mu \mathrm{g} / \mathrm{ml})$} \\
\cline { 2 - 5 } & $\begin{array}{c}\text { DPPH radical } \\
\text { scavenging assay }\end{array}$ & $\begin{array}{c}\text { ABTS radical scavenging } \\
\text { assay }\end{array}$ & $\begin{array}{c}\text { Hydrogen peroxide } \\
\text { assay }\end{array}$ & Phosphomolybdate assay \\
\hline Ascorbic acid & 57.39 & 53.22 & 46.68 & 53.83 \\
REE & 127.84 & 125.01 & 117.05 & 125.77 \\
RME & 147.70 & 137.30 & 132.27 & 178.79 \\
\hline
\end{tabular}
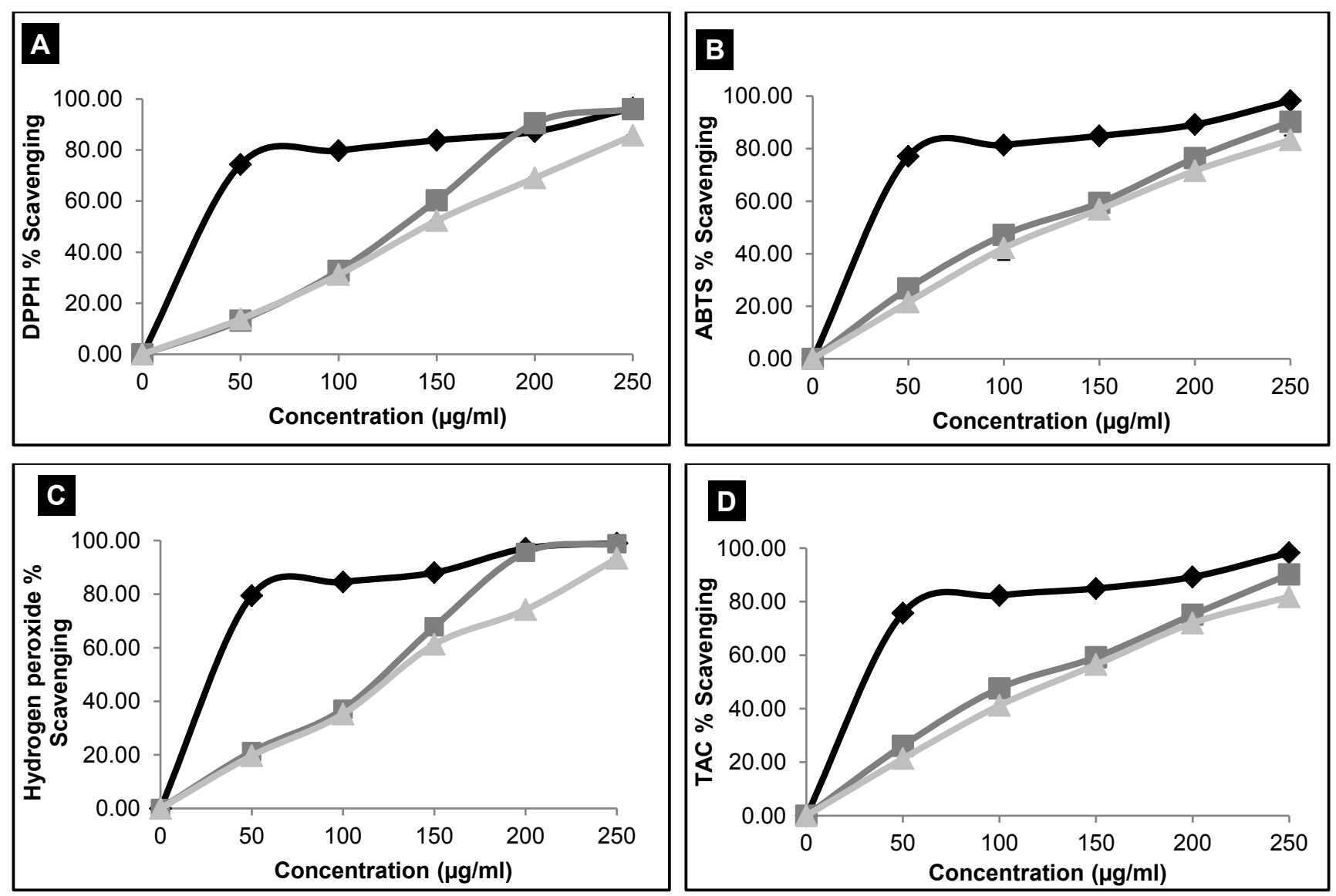

Fig. 3: Antioxidant activity study of ascorbic acid

REE and RME using (A) DPPH radical scavenging assay, (B) ABTS radical scavenging assay, (C) hydrogen peroxide assay and (D) phosphomolybdate assay. All the results are mean \pm SD $(n=3) .-\bullet-$ Ascorbic acid; $-\square-(\mathrm{REE})$ rhizome ethanol extract; $-\Delta-$ (RME) rhizome methanol extract 


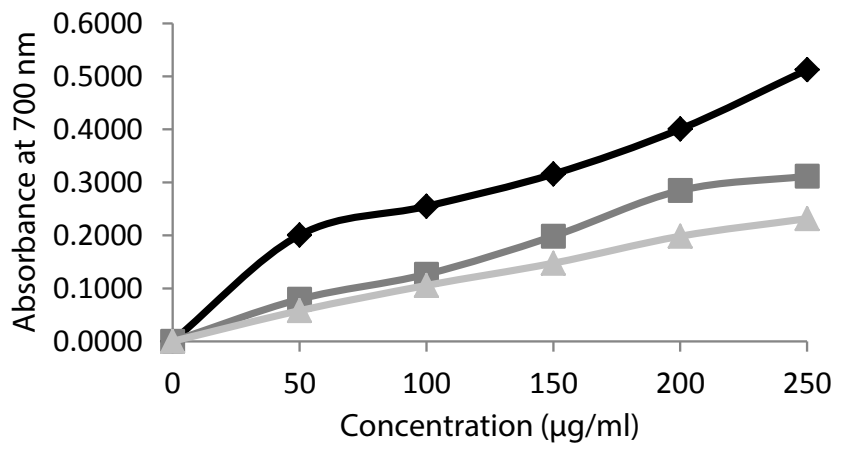

Fig. 4: Reducing power assay

All the results are mean \pm SD $(n=3),-\uparrow-$ ascorbic acid; $-\square-$ (REE) rhizome ethanol extract; $-\Delta-$ (RME) rhizome methanol extract

TABLE 3: STATISTICAL EVALUATION (ONE-WAY ANOVA) OF THE EXTRACTS (REE AND RME) WITH DIFFERENT ANTIOXIDANT ASSAY METHODS. (SIGNIFICANCE LEVEL, $A=0.05$ )

\begin{tabular}{lcc}
\hline Method & F-value & P-value \\
\hline DPPH radical scavenging assay & 0.547 & 0.466 \\
ABTS radical scavenging assay & 0.347 & 0.561 \\
$\mathrm{H}_{2} \mathrm{O}_{2}$ radical scavenging assay & 0.457 & 0.505 \\
Phosphomolybdate assay & 0.384 & 0.541 \\
Reducing power & 3.207 & 0.084 \\
\hline
\end{tabular}

related to the carrier solvent, DMSO, which diffused effortlessly across the medium ${ }^{[10]}$. Here, DMSO is used as a solvent for dissolving REE and RME in the antibacterial study. DMSO is a dipolar aprotic solvent that has the ability to dissolve both polar and nonpolar compounds. DMSO is used as a cryoprotectant for subzero temperature fractionation and long term low temperature conservation of various biomaterials ${ }^{[39]}$ and thus considered to have no effect on the growth of microorganisms. Though the literature supports the use of DMSO as solvent for antibacterial studies, a negative control of DMSO is also included in each plate to be extra sure.

In the present scenario rising resistance by many organisms worldwide towards the antibacterial usually in use $\mathrm{e}^{[40]}$, it is very important that the actual ingredients having antibacterial potential needs to be extracted. The present study is helpful in finding the extract which showed better antibacterial activity. Literature survey revealed the fact that $H$. rostrata when extracted with $70 \% \mathrm{w} / \mathrm{v}$ ethanol showed no antibacterial activity at a concentration of $10 \mathrm{mg} / \mathrm{ml}^{[30]}$. Chavasco et al. reasoned that this could be due to the solvent chosen for extraction such as $70 \% \mathrm{w} / \mathrm{v}$ ethanol, which failed to extract the active constituents responsible for antibacterial activity. In this study, $70 \%$ ethanol was replaced with absolute ethanol and methanol as solvents for extraction. This study also compared the antibacterial activity of ethanol and methanol extracts of rhizome of $H$. rostrata, REE and RME, respectively at the same concentration of 10 $\mathrm{mg} / \mathrm{ml}$. Results presented in figs. 5 and 6 demonstrated that both REE and RME at the concentration 10 $\mathrm{mg} / \mathrm{ml}$ exerted antibacterial activity against Grampositive and Gram-negative bacteria. DMSO showed no antibacterial activity. The antibacterial activity of REE and RME might be attributed to the TPC, TTC and TFC in REE and RME. The very high levels of TFC and TPC in REE compared to RME might have resulted in the greater antibacterial potency of REE, since flavonoids and phenolic compounds are believed to be playing a role protecting plants against microbial attack $^{[37]}$. Tannins also act as astringents and have the ability to bind, precipitate or shrink proteins ${ }^{[41]}$. This ability of tannins could directly damage the bacterial cell wall, precipitate bacterial proteins leading to the death of bacteria ${ }^{[42,43]}$. The presence of tannin in RME could be the reason for the antibacterial activity of RME. The ZI obtained in this investigation have been shown in Table 4 and from the figs. 5 and 6, which compares the ZI formed by REE and RME against different bacteria, it would be possible to state that REE exhibited greater antibacterial activity when compared to RME. Both REE and RME failed to show any ZI against $K$. pneumonia. Concentrations higher than 10 $\mathrm{mg} / \mathrm{ml}$ might be effective against this bacterium.

MIC is the lowest concentration of extract that prevented the visible microbial growth $^{[44]}$. 2,3,5-Triphenyl tetrazolium chloride is used as a growth indicator in the MIC determinations. 2,3,5-Triphenyl tetrazolium chloride is a white crystalline compound. It is a redox indicator, which is used to distinguish between metabolically active and sedentary tissues. The white coloured 2,3,5-triphenyl tetrazolium chloride reduced to pink/red coloured 1,3,5-triphenyl formazan (TPF) in the presence of living tissues due to the activity of various enzymes important in cellular metabolism ${ }^{[45,46]}$. 2,3,5-Triphenyl tetrazolium chloride at concentration $>0.125 \%$ did not show any inhibitory effect on the bacterial growth and concentrations $<0.003 \%$ did not exhibit a change in colour ${ }^{[47]}$. Thus, MIC is taken to be the lowest concentration in which the pink colouration is not observed. MIC values of REE were lower than or equal to those of RME against all bacteria tested. $\mathrm{MBC}$ is the lowest concentration of the extract at which no bacterial growth is observed after sub-culture on to an antimicrobial free medium. The MBC of REE and RME against all the bacteria except $P$. aeruginosa were found well within $10 \mathrm{mg} / \mathrm{ml}$. MIC and MBC of 


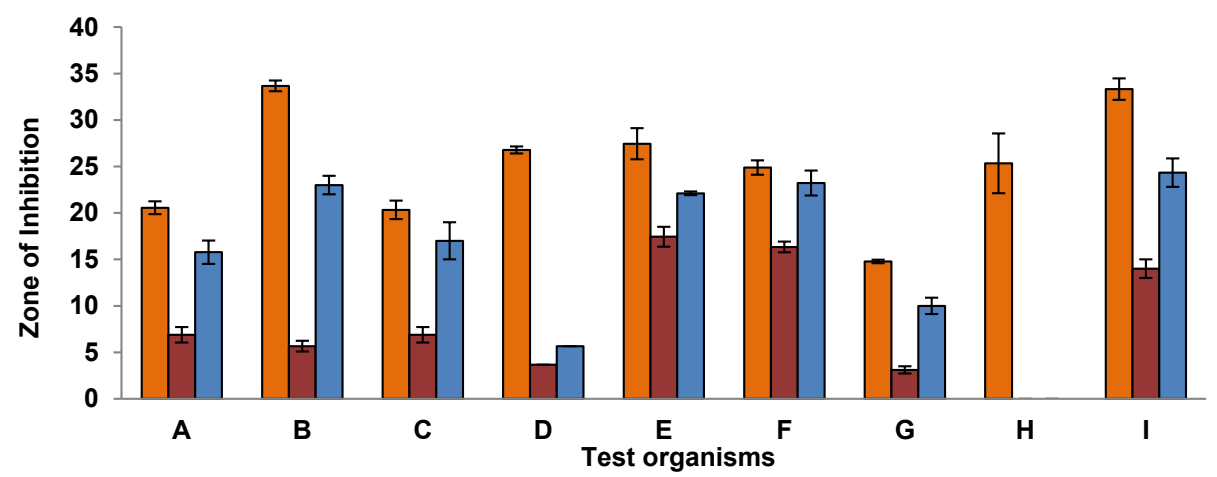

Fig. 5: Zone of inhibition of various bacteria for positive control

RME and REE where, (A) Staphylococcus aureus, (B) Bacillus stereothermophillus, (C) Bacillus subtilis, (D) Pseudomonas aeruginosa, (E) Vibrio cholera, (F) Escherichia coli, (G) Acinetobacter baumanni, (H) Klebsiella Pneumoniae and (I) Salmonella enterica. All the results are mean \pm SD $(n=3)$. $\backsim$ Positive control $\backsim(R M E)$ rhizome methanol extract $\backsim($ REE) rhizome ethanol extract
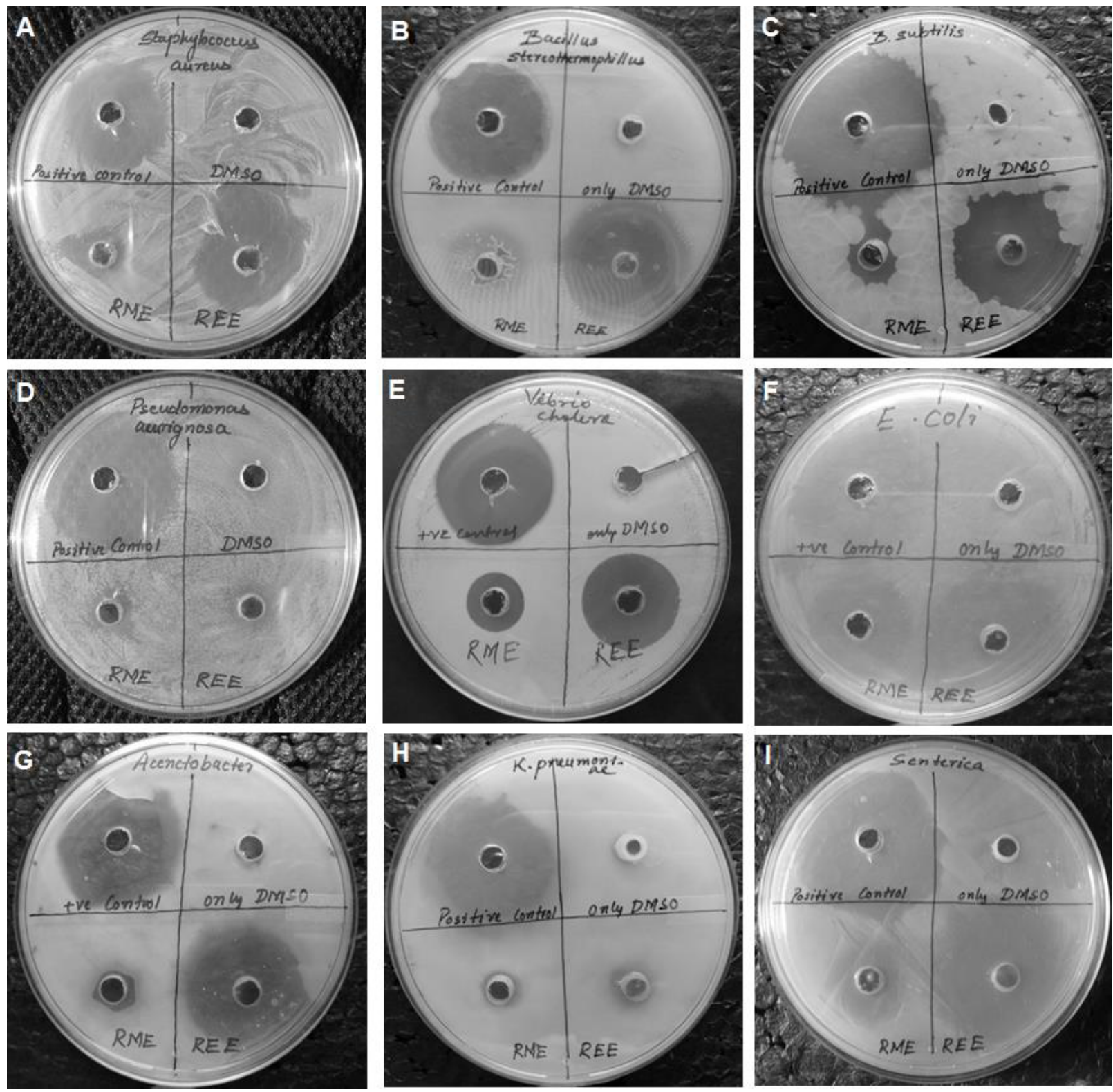

Fig. 6: Antibacterial study

RME and REE against (A) Staphylococcus aureus, (B) Bacillus stereothermophillus, (C) Bacillus subtilis, (D) Pseudomonas aeruginosa, (E) Vibrio cholera, (F) Escherichia coli, (G) Acinetobacter baumannii, (H) Klebsiella Pneumoniae and (I) Salmonella enterica 
TABLE 4: ZONE OF INHIBITION (ZI), MINIMUM INHIBITORY CONCENTRATION (MIC), MINIMUM BACTERICIDAL CONCENTRATION (MBC)

\begin{tabular}{|c|c|c|c|c|c|c|}
\hline Test organism & Test sample & $\mathrm{Zl} \pm \mathrm{SD}(\mathrm{mm})$ & MIC & MBC & F-value & P-value \\
\hline \multirow[t]{4}{*}{ S. aureus ${ }^{*}$} & DMSO & 0 & & ND & & \\
\hline & Positive control & $20.56 \pm 0.69$ & & & & \\
\hline & REE & $15.78 \pm 1.26$ & $<4 \mathrm{mg} / \mathrm{ml}$ & $<4 \mathrm{mg} / \mathrm{ml}$ & 103.22 & 0.001 \\
\hline & RME & $6.89 \pm 0.84$ & $<4 \mathrm{mg} / \mathrm{ml}$ & $<4 \mathrm{mg} / \mathrm{ml}$ & & \\
\hline \multirow[t]{4}{*}{ B. subtilis* } & DMSO & 0 & & ND & & \\
\hline & Positive control & $33.67 \pm 0.58$ & & & & \\
\hline & REE & $23.00 \pm 1.00$ & $<2 \mathrm{mg} / \mathrm{ml}$ & $<2 \mathrm{mg} / \mathrm{ml}$ & 676.00 & 0.000 \\
\hline & RME & $5.67 \pm 0.58$ & $<1 \mathrm{mg} / \mathrm{ml}$ & $<4 \mathrm{mg} / \mathrm{ml}$ & & \\
\hline \multirow[t]{4}{*}{ B. stereothermophillus* } & DMSO & 0 & & ND & & \\
\hline & Positive control & $20.33 \pm 1.00$ & & & & \\
\hline & REE & $17.00 \pm 2.00$ & $<1 \mathrm{mg} / \mathrm{ml}$ & $<1 \mathrm{mg} / \mathrm{ml}$ & 65.21 & 0.001 \\
\hline & RME & $6.89 \pm 0.84$ & $<1 \mathrm{mg} / \mathrm{ml}$ & $<2 \mathrm{mg} / \mathrm{ml}$ & & \\
\hline \multirow[t]{4}{*}{ P. aeruignosa } & DMSO & 0 & & ND & & \\
\hline & Positive control & $26.78 \pm 0.38$ & & & & \\
\hline & REE & $5.67 \pm 0.00$ & $<4 \mathrm{mg} / \mathrm{ml}$ & $>10 \mathrm{mg} / \mathrm{ml}$ & NF & $\mathrm{NF}$ \\
\hline & RME & $3.67 \pm 0.00$ & $<8 \mathrm{mg} / \mathrm{ml}$ & $>10 \mathrm{mg} / \mathrm{ml}$ & & \\
\hline \multirow[t]{4}{*}{ V. cholerae } & DMSO & 0 & & ND & & \\
\hline & Positive control & $27.44 \pm 1.68$ & & & & \\
\hline & REE & $22.11 \pm 0.19$ & $<1 \mathrm{mg} / \mathrm{ml}$ & $<1 \mathrm{mg} / \mathrm{ml}$ & 55.13 & 0.002 \\
\hline & RME & $17.44 \pm 1.07$ & $<1 \mathrm{mg} / \mathrm{ml}$ & $<1 \mathrm{mg} / \mathrm{ml}$ & & \\
\hline \multirow[t]{4}{*}{ E. coli } & DMSO & 0 & & ND & & \\
\hline & Positive control & $24.89 \pm 0.77$ & & & & \\
\hline & REE & $23.22 \pm 1.35$ & $<1 \mathrm{mg} / \mathrm{ml}$ & $<1 \mathrm{mg} / \mathrm{ml}$ & 66.27 & 0.001 \\
\hline & RME & $16.33 \pm 0.58$ & $<2 \mathrm{mg} / \mathrm{ml}$ & $<2 \mathrm{mg} / \mathrm{ml}$ & & \\
\hline \multirow[t]{4}{*}{ A. baumannii } & DMSO & 0 & & ND & & \\
\hline & Positive control & $14.78 \pm 0.19$ & & & & \\
\hline & REE & $10.00 \pm 0.88$ & $<1 \mathrm{mg} / \mathrm{ml}$ & $<1 \mathrm{mg} / \mathrm{ml}$ & 165.37 & 0.000 \\
\hline & RME & $3.11 \pm 0.38$ & $<1 \mathrm{mg} / \mathrm{ml}$ & $<1 \mathrm{mg} / \mathrm{ml}$ & & \\
\hline \multirow[t]{4}{*}{ K. pneumonia } & DMSO & 0 & & ND & & \\
\hline & Positive control & $25.33 \pm 3.21$ & & & & \\
\hline & REE & 0 & $\mathrm{NF}$ & $\mathrm{NF}$ & NF & $\mathrm{NF}$ \\
\hline & RME & 0 & NF & $\mathrm{NF}$ & & \\
\hline \multirow[t]{4}{*}{ S. enterica } & DMSO & 0 & & ND & & \\
\hline & Positive ontrol & $33.33 \pm 1.15$ & & & & \\
\hline & REE & $24.33 \pm 1.53$ & $<1 \mathrm{mg} / \mathrm{ml}$ & $<1 \mathrm{mg} / \mathrm{ml}$ & 96.10 & 0.001 \\
\hline & RME & $14.00 \pm 1.00$ & $<1 \mathrm{mg} / \mathrm{ml}$ & $<4 \mathrm{mg} / \mathrm{ml}$ & & \\
\hline
\end{tabular}

Statistical evaluation of the extracts (REE and RME) against different Gram-positive and Gram-negative bacteria. All the results are mean \pm SD $(n=3)$. (Significance level, $a=0.05)$. Marked bacteria are Gram-positives and rest are Gram-negatives. ND=Not Done, NF=Not found.

REE and RME were not determined for K. pneumonia, since no ZI could be observed at $10 \mathrm{mg} / \mathrm{ml}$. Results presented in figs. 5 and 6 and Table 4 indicated that REE showed significantly higher antibacterial activity compared to that of RME.

Rhizomes of $H$. rostrata were extracted to obtain REE and RME. Both REE and RME were subjected to phytochemical screening and were found to contain flavonoids, proteins and amino acids, carbohydrates and reducing sugars, tannins and saponins except for glycosides, which were found only in RME. TPC and TFC is more in REE while TTC was more in RME. Both REE and RME showed no significant difference in their antioxidant potential while, REE was found to have greater antibacterial activity.

\section{Acknowledgements:}

The authors sincerely acknowledge the support of Pharmaceutical Sciences, SOA University for providing all the amenities and environment to execute this work. Authors also sincerely thank the Regional Plant Resource Centre (RPRC), Bhubaneswar for providing the plant and authenticating it. The authors also wish to thank the Department of Microbiology, IMS and SUM Hospital, Bhubaneswar for providing the bacterial strains for antibacterial study. 


\section{Conflict of interest:}

There are no conflicts of interest.

\section{Financial support and sponsorship:}

Nil.

\section{REFERENCES}

1. Kumbhare MR, Guleha V, Sivakumar T. Estimation of total phenolic content, cytotoxicity and in vitro antioxidant activity of stem bark of Moringa oleifera. Asian Pac J Trop Dis 2012:144-50.

2. Handique L, Prakash V, Hazarika AD. Phylogeny of Musa paradisiaca, Ravenala madagascariensis and Heliconia rostrata based on morphological, biochemical, amino acid sequences of rbcl protein and matK DNA sequences. Int $\mathrm{J}$ Theor Appl Sci 2013;5:69-78.

3. Estrada SG, Quintana JC, Jimenez SL, Alarcon JC, Pereanez JA, Vargas LJ, et al. Preliminary phytochemistry assessment of Heliconia psittacorum and $H$. rostrata and the potential inhibitory activity of some effects of Bothrops asper (mapana X) Venom. Vitae 2009;16:252-7.

4. Gunjan M, Karna L, Dayalan K, Sasigaran P. A review and search of phytomedicine used by traditional people of Malaysia (Ipoh, Perak). Int J Phytother Res 2012;21:26-41.

5. Aruoma OI. Free radicals, oxidative stress, and antioxidants in human health and disease. J Amer Oil Chem Soc 1998;75:199212.

6. Jayaprakasha GK, Rao LJ, Sakariah KK. Antioxidant activities of flavidin in different in vitro model systems. Bioorg Med Chem 2004; 12:5141-6.

7. Muniandy P, Shori AB, Baba AS. Influence of green, white and black tea addition on the probiotic yogurt during refrigerated storage. Food Packaging Shelf Life 2016;8:1-8.

8. Vhangani LN, Wyk JV. Antioxidant activity of Maillard reaction products (MRPs) in a lipid-rich model system. Food Chem 2016;208:301-8.

9. Recio MC, Rios JL. A review of some antimicrobial compounds isolated from medicinal plants reported in the literature 1978-1988. Phytother Res 1989;3:117-25.

10. Valgas C, DeSouza MS, Smania EFA, Smania A. Screening methods to determine antibacterial activity of natural products. Braz J Microbiol 2007;38:369-80.

11. Silver LL, Bostion KA. Discovery and development of new antibiotics: The problem of antibiotic resistance. Antimicrob Agents Chemother 1993;37:377-83.

12. Victor BYA, Grace A. Phytochemical studies, in vitro antibacterial activities and antioxidant properties of the methanolic and ethyl acetate extracts of the leaves of Anogeissus leiocarpus. IJBCRR 2013;3:137-45.

13. Ng C, Ko C, Koon C, Xian J, Leung P, Fung K, et al. The aqueous extract of rhizome of Gastrodia elata protected Drosophila and PC12 Cells against beta-amyloid-induced neurotoxicity. J Evid Based Complementary Altern Med 2013:516741.

14. Bae K, Choi Y, Kim S, Kim Y. Components of rhizome extract of Cnidium officinale Makino and their in vitro biological effects. Molecules 2011;16:8833-47.

15. Abbasi MA, Saleem H, Rehman A, Riaz T, Ajaib M. Determination of antioxidant activity and phytoconstituent screening of Euphorbia heterophylla Linn. British J Pharma Res 2013;3:202-16.

16. Alabri THA, Musalami AHSA, Hossain MA, Weli AM, AlRiyami Q. Comparative study of phytochemical screening, antioxidant and antimicrobial capacities of fresh and dry leaves crude plant extracts of Datura metel L. J King Saud Univ Sci 2014;26:237-43.

17. Ismail AM, Mohamed EA, Marghany MR, Abdel-Motaal FF, Abdel-Farid IB, El-Sayed MA. Preliminary phytochemical screening, plant growth inhibition and antimicrobial activity studies of Faidherbia albida legume extracts. J Saudi Soc Agric Sci 2014:1-6.

18. Ahmed D, Fatima M, Saeed S. Phenolic and flavonoid contents antioxidative potential of epicarp and mesocarp of Lageneria siceraria fruit: a comparative study. Asian Pac J Trop Med 2014;7:S249-S55.

19. Rahate KP, Padma R, Parvathy NG, Renjith V. Quantitative estimation of tannins, phenols and antioxidant activity of methanolic extract of Imperata cylindrical. Int J Res Pharm Sci 2013;4:73-7.

20. Park Y, Jung S, Kang S, Heo BG, Arancibia-Avila A, Toledo $\mathrm{F}$, et al. Antioxidants and proteins in ethylene-treated kiwifruits. Food Chem 2008;107:640-8.

21. Saeed N, Khan MR, Shabbir M. Antioxidant activity, total phenolic and total flavonoid contents of whole plant extracts Torilis leptophylla L. BMC Complement Altern Med 2012;12:1-12.

22. Haddouchi F, Chaouche TM, Ksouri R, Medini F, Sekkal FZ, Benmansour A. Antioxidant activity profiling by spectrophotometric methods of aqueous methanolic extracts of Helichrysum stoechas Rupestre and Phagnalon saxatile Saxatile. Chin J Nat Med 2014;12:0415-22.

23. Alhaji UI, Samuel NU, Aminu M, Chidi AV, Umar ZU, Umar $\mathrm{UA}$, et. al. In vitro antitrypanosomal activity, antioxidant property and phytochemical constituents of aqueous extracts of nine Nigerian medicinal plants. Asian Pac J Trop Med 2014;45:348-55.

24. Moein MR, Moein S, Ahmadizadeh S. Radical scavenging and reducing power of Salvia mirzayanii subfractions. Molecules 2008;13:2804-13.

25. Ferreira ICFR, Baptista P, Vilas-Boas M, Barros L. Free radical scavenging capacity and reducing power of wild edible mushroom from Northeast Portugal: Individual cap and stipe activity. Food Chem 2007;100:1511-16.

26. Chitravadivu C, Manian S, Kalaichelvi K. Antimicrobial studies on selected medicinal plants, Erode region, Tamilnadu, India. Middle-East J Sci Res 2009;4:147-52.

27. Nashwa T, Hassan HM, AbdelGhani SMM, Radwan IA, Hammouda O. Comparative chemical and antimicrobial study of nine essential oils obtained from medicinal plants growing in Egypt. Beni-Suef Univ J Appl Sci 2014;3:149-56.

28. De Araujo AA, Soares LAL, Ferreira MRA, Neto MAD, De Silva GR, De Araujo RF, et al. Quantification of polyphenols and evaluation of antimicrobial, analgesic and antiinflammatory activities of aqueous and acetone-water extracts of Libidibia ferrea, Parapiptadenia rigida and Psidium guajava. J Ethnopharmacol 2014;156:88-96.

29. Anokwuru CP, Adaramola FB, Akirinbola D, Fagbemi E, Onikoyi F. Antioxidant and Antidenaturing activities of defatted and non-defatted methanolic extracts of three medicinal plants in Nigeria. Researcher 2012;4:56-62.

30. Chavasco JM, PradoEFeliphe BHN, Cerdeira CD, Leandro 
FD, Coelho LFL, Silva JJ, et al. Evaluation of Antimicrobial and cytotoxic activities of plant extracts from Southern Minas Gerais Cerrado. Rev Inst Med Trop Sao Paulo 2014;56:13-20.

31. Estrada SG, Jimenez LS, Alarcon CPJ, Vargas JL. Application of ultrasound in the dissolution of potential antiophidian compounds from ethanolic extracts of two species of Heliconias. Ultrason Sonochem 2010;17:756-9.

32. Shekhar TC, Anju G. Antioxidant activity by DPPH Radical Scavenging method of Ageratum conyzoides Linn. Leaves. Am J Ethnomed 2014;1:244-9.

33. Shalaby EA, Shanab SMM. Comparison of DPPH and ABTS assays for determining antioxidant potential of water and methanol extracts of Spirulina platensis. Indian J Mar Sci 2013;42:556-64.

34. Fernando CD, Soysa P. Optimized enzymatic colorimetric assay for determination of hydrogen peroxide $\left(\mathrm{H}_{2} \mathrm{O}_{2}\right)$ scavenging activity of plant extracts. Methods X 2015;2:283-91.

35. Keser S, Celik S, Turkoglu S, Yilmaz O, Turkoglu I. Hydrogen peroxide radical scavenging and total antioxidant activity of hawthorn. Chem J 2012;21:9-12.

36. Iqbal $\mathrm{P}$, Ahmed $\mathrm{D}$, Asghar $\mathrm{MN}$. A comparative in vitro antioxidant potential profile of extracts from different parts of Fagonia cretica. Asian Pac J Trop Med 2014;7:S473-S80.

37. Harborne JB, Williams CA. Advances in flavonoid research since 1992. Phytochemistry 2000;55:481-504.

38. Kumaran A, Karunakaran RJ. In vitro antioxidant activities of methanol extracts of five Phyllanthus species from India. LWT Food Sci Technol 2007;40:344-52.

39. Huang P, Dong A, Caughey WS. Effects of dimethyl sulfoxide, glycerol and ethylene glycol on secondary structures of cytochrome $\mathrm{C}$ and lysozyme as observed by infrared spectroscopy. J Pharm Sci 1995;84:387-92.
40. Zheng B, Li A, Jiang X, Hu X, Yao J, Zhao L, et al. Genome sequencing and genomic characterization of a tigecyclineresistant Klebsiella pneumoniae strain isolated from the bile samples of a cholangiocarcinoma patient. Gut Pathogens 2014;6:1-7.

41. Ashok PK, Upadhaya K. Tannins are astringent. J Pharm Phytochem 2012;1:45-50.

42. Baskaran C, Rathabai V, Kanimozhi D. Screening of antimicrobial activity and phytochemical analysis of various leaf extract of Murraya koenigii. Int J Res Ayurveda Pharm 2011;2:1807-10.

43. Taveria-de-Jesus NZ, Falcao HDS, Gomes IF, Leite TJDA, Lima GRDM, Babosa-Filho JM, et al. Tannins, peptic ulcer and related mechanisms. Int J Mol Sci 2012;13:3203-28.

44. Mbosso EJT, Ngouela S, Nguedia JCA, Beng VP, Rohmer $\mathrm{M}$, Tsamo E. In vitro antimicrobial activity of extracts and compounds of some selected medicinal plants from Cameroon. J Ethnopharmacol 2010;128:476-81.

45. Otero AJ, Rodriguez I, Gustavo F. 2,3,5-triphenyl tetrazolium chloride (TTC) reduction as exponential growth phase marker for mammalian cells in culture and myeloma hybridization experiments. Cytotechnology 1991;6:137-42.

46. Beloti V, Barros MAF, De-Freitas JC, Nero LA, De-Souza JA, Santana EHW, et al. Frequency of 2,3,5-triphenyltetrazolium chloride (TTC) Non-reducing bacteria in Pasteurized milk. Rev. Microbiol 1999;30:137-40.

47. Rahman M, Kuhn I, Rahman M, Olsson-Liljequist B, Molby R. Evaluation of a scanner-assisted colorimetric MIC method for susceptibility testing of Gram-negative fermentative bacteria. Appl Environ Microbiol 2004;70:2398-403. 